\title{
The influence of riparian vegetation shading on water temperature during low flow conditions in a medium sized river
}

\author{
Gerda Kalny ${ }^{1, *}$, Gregor Laaha ${ }^{4}$, Andreas Melcher $^{3}$, Heidelinde Trimmel $^{2}$, Philipp Weihs ${ }^{2}$ and \\ Hans Peter Rauch ${ }^{1}$ \\ ${ }^{1}$ Institute of Soil Bioengineering and Landscape Construction, Department of Civil Engineering and Natural Hazards, University of \\ Natural Resources and Life Sciences Vienna, Peter Jordan-Strasse 82, Vienna 1190, Austria \\ 2 Institute of Meteorology, Department of Water, Atmosphere and Environment, University of Natural Resources and Life Sciences \\ Vienna, Gregor Mendel Strasse 33, Vienna 1180, Austria \\ ${ }^{3}$ Institute of Hydrobiology and Aquatic Ecosystem Management, Department of Water, Atmosphere and Environment, University of \\ Natural Resources and Life Sciences Vienna, Gregor Mendel Strasse 33, Vienna 1180, Austria \\ ${ }^{4}$ Institute of Applied Statistics and Computing, Department of Landscape, Spatial and Infrastructure Science, University of Natural \\ Resources and Life Sciences Vienna, Peter Jordan-Strasse 82, Vienna 1190, Austria
}

\begin{abstract}
Stream water temperature limits the growth and survival of aquatic organisms; whereby riparian shading plays a key role in inhibiting river warming. This study explains the effects of riparian shading on summer water temperatures at a pre-alpine Austrian river, during heatwave and nonheatwave periods at low flow conditions. A vegetation-shading index was introduced for the quantification of riparian vegetation effects on water temperature. For maximum water temperatures, a downstream warming of $3.9^{\circ} \mathrm{C}$ was observed in unshaded areas, followed by a downstream cooling of $3.5^{\circ} \mathrm{C}$ in shaded reaches. Water temperature directly responded to air temperature and cloudiness. For an air temperature change of $2{ }^{\circ} \mathrm{C}$ we modelled a water temperature change of $1.3^{\circ} \mathrm{C}$ for unshaded reaches, but lower changes for intensively shaded reaches. Similar daily variations at shaded reaches were up to $4{ }^{\circ} \mathrm{C}$ lower than unshaded ones. This study gives clear evidence that for a medium-sized prealpine river, restoration practices should consider that discontinuity of riparian vegetation should be less than $6000 \mathrm{~m}$; with more than $40 \%$ dense vegetation in order to minimize water temperature increases due to unshaded conditions.
\end{abstract}

Keywords: riparian vegetation / vegetation-shading index / water temperature / river vegetation management / restoration

\begin{abstract}
Résumé - L'influence de la végétation rivulaire sur la température de l'eau pendant les conditions de faible débit dans une rivière de taille moyenne. La température de l'eau d'une rivière limite la croissance et la survie des organismes aquatiques; de ce fait l'ombrage rivulaire joue un rôle clé dans la limitation du réchauffement des rivières. Cette étude analyse les effets de l'ombrage rivulaire sur les températures estivales de l'eau dans une rivière autrichienne préalpine, pendant les périodes de canicule et de non-canicule à faible débit. Un indice d'ombrage de la végétation a été introduit pour la quantification des effets de la végétation rivulaire sur la température de l'eau. Pour les températures maximales de l'eau, un réchauffement en aval de $3,9^{\circ} \mathrm{C}$ a été observé dans les zones non ombragées, suivi d'un refroidissement en aval de $3,5^{\circ} \mathrm{C}$ dans les zones ombragées. La température de l'eau a répondu directement à la température de l'air et à la nébulosité. Pour un changement de température de l'air de $2{ }^{\circ} \mathrm{C}$, nous avons modélisé un changement de température de l'eau de $1,3{ }^{\circ} \mathrm{C}$ pour les zones non ombragées, mais des changements plus faibles pour les niveaux intensivement ombragés. Des variations quotidiennes semblables dans des zones ombragées étaient jusqu'à $4{ }^{\circ} \mathrm{C}$ inférieures à celles non ombragées. Cette étude montre clairement que pour une rivière préalpine de taille moyenne, les pratiques de restauration devraient considérer que la discontinuité de la végétation riveraine doit être
\end{abstract}

\footnotetext{
* Corresponding author: gerda.kalny@boku.ac.at
} 
inférieure à $6000 \mathrm{~m}$, avec plus de $40 \%$ de végétation dense afin de minimiser les augmentations de température de l'eau dues aux conditions non ombragées.

Mots clés : végétation riveraine / indice d'ombrage de la végétation / température de l'eau / gestion de la végétation des rivières / restauration

\section{Introduction}

Stream water temperature is an important and limiting parameter for a number of organisms such as fish or aquatic invertebrates (Broadmeadow and Nisbet, 2004; Matulla et al., 2007; Rahel and Olden, 2008; Logez and Pont, 2013; Pletterbauer et al., 2014). It results from the multiple processes, which influence the gains and losses of thermal energy in streambeds, depending on the amount of stream discharge, topography and atmospheric conditions along the river course (Caissie, 2006). Upstream water temperature and discharge, hyporheic exchange, ground water inflow, bed heat conduction, tributary inflow and its water temperature, turbulent exchange (sensible and latent heat), solar radiation (incident, reflected), and long wave radiation are components of these processes (Moore et al., 2005; Caissie, 2006). Taking into consideration atmospheric conditions, air temperature and incoming short-wave radiation are mentioned as major influencing factors on water temperatures by Evans et al. (1998). They recorded total energy gains dominated by a net short-wave radiation of $97.6 \%$. Solar radiation reaching the stream is influenced by different topographic factors, including the prevailing riparian vegetation buffer, which can decrease incoming energy by up to 95\% (Rutherford et al., 1997; Moore et al., 2005; DeWalle, 2010). During summer heatwave periods in particular, solar energy plays a key role in influencing stream energy heat budget, and consequently stream water temperature (Johnson, 2004; Leach and Moore, 2010; Groom et al., 2011). Hence shading through riparian vegetation, primarily in small to medium sized and slowly flowing lowland rivers, is often most relevant to avoid excessive heating in order to mitigate adverse effects on the ecosystem (Ghermandi et al., 2009; He et al., 2011; Holzapfel et al., 2013).

Some studies were undertaken to quantify the influence of riparian vegetation on river water temperature, however, they have mainly explored small rivers, with a discharge of up to only 301/s (Story et al., 2003; Johnson, 2004; Rutherford et al., 2004; Moore et al., 2005; Gomi et al., 2006). The most widely discussed vegetation parameters of these studies are buffer width, vegetation height and its density. For instance DeWalle (2010) specifies varying minimum buffer widths for sufficient shading, and corresponding water temperature influence, depending on stream orientation. Buffer widths for east-west oriented rivers necessitate a minimum buffer width of 6-7 m, whereas for north-south orientated rivers the buffer width needs to be $18-20 \mathrm{~m}$, and for meandering rivers no more than $12 \mathrm{~m}$. According to Sridhar et al. (2004), vegetation width exceeding $30 \mathrm{~m}$ distance has hardly any further influence on stream water temperature. However, the height and density of the riparian vegetation have an equal or even higher impact on water temperature (Sridhar et al., 2004; DeWalle, 2010). DaviesColley et al. (2009) and DeWalle (2008) showed that the ratio of canopy height to stream width has particular high influence on stream light exposure and is therefore notably relevant.
Apart from riparian vegetation structures, also the temperature conditions of river and atmosphere determine the cooling effect of vegetation. Cooling occurs when energy gains are reduced by riparian vegetation, which minimizes water temperature increase, so that the influence of cooler water is prevalent (Garner et al., 2014). The cooling effect is greater at high water temperatures, typically occurring during heatwaves and at daily temperature peaks (Moore et al., 2005) whereas there is only a minor effect of vegetation shading on daily temperature minima (Rutherford et al., 2004).

However, these findings primarily apply to smaller rivers, which are usually shallow, so they adjust quickly to incoming solar radiation. Consequently, water temperature changes are rather fast (Moore et al., 2005), and riparian vegetation influence can be high (Poole and Berman, 2001). The effect of shading might be different for larger rivers where water temperature fluctuations are normally lower (Poole and Berman, 2001) and solar radiation may play a different role, but these effects are not fully explored yet. Moreover, studies investigating riparian shade and its impact on stream water temperatures have been carried out in most temperate regions of the world, but up to date only a few studies have been conducted in Europe (Ghermandi et al., 2009; Broadmeadow et al., 2011; Garner et al., 2014; Johnson and Wilby, 2015). So far, studies, focusing on effects of riparian vegetation on water temperature of medium sized rivers are missing, especially for Central European climates where climate change impacts are predicted to be high (Kovats et al., 2014; Laaha et al., 2016).

The aim of this study is to analyse the effects and mitigation evidence of different river type specific riparian vegetation on summer river water temperature, under heatwave and non-heatwave conditions at a medium sized river in Central Europe. The specific objectives are (i) to describe the summer temperature regime during heatwave and non-heatwave periods (ii) to better understand longitudinal riparian vegetation shading impacts on water temperature by introducing a new vegetation-shading index (VSI), (iii) to explore the sensitivity of VSI to the section length used in its calculation and (iv) to validate the effects of shaded and unshaded river reaches on water temperature variations. The findings will be discussed in the light of riparian vegetation management.

\section{Materials and methods}

\subsection{Study site}

The study was conducted at the river Pinka, located in the south-east of Austria (Fig. 1). In this area, in particular, climate change impacts are predicted to be high, in terms of an increase of heatwaves and exacerbation of low flow conditions (Kovats et al., 2014; Laaha et al., 2016). The river source is at an altitude of about $1480 \mathrm{~m}$.a.s.l, and it discharges into the river Raab at about 200 m.a.s.l. Along the river, mean discharge increases up to $2.0 \mathrm{~m}^{3} / \mathrm{s}$. The study area belongs to the trout, 


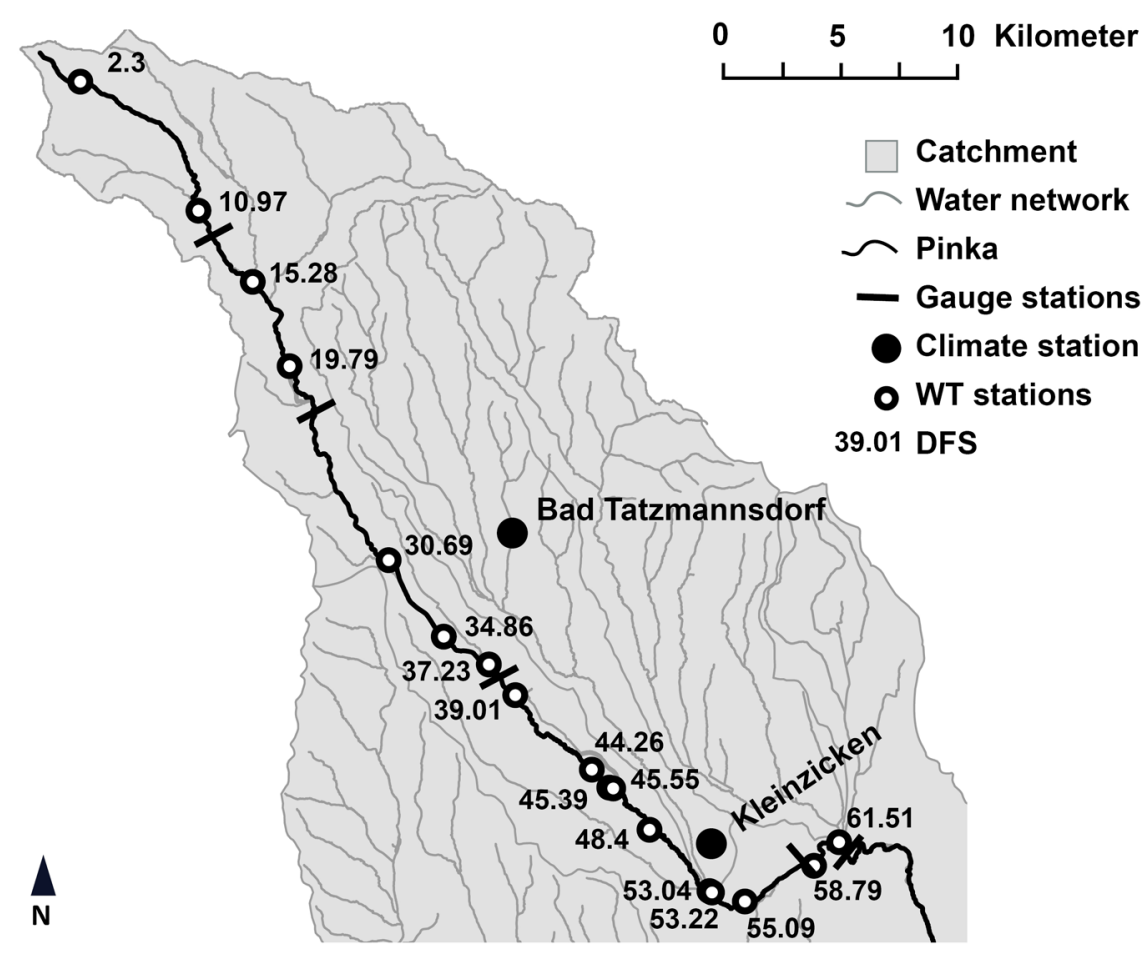

Fig. 1. Study site - the river Pinka from distance from source (DFS) 0-DFS 62 including river course, tributaries, gauge stations, water temperature (WT) measuring stations and climate stations.

grayling and barbel fishzone, bearing 24 fish species and 140 benthic taxa (Melcher et al., 2016).

The catchment is situated at a transition zone of alpine, illyric and continental climate. It is characterised by a mean annual rainfall of about $800 \mathrm{~mm}$, frequent thunderstorms, heavy rainfalls (Cejka et al., 2005) and high temperature amplitudes between summer and winter (Fink et al., 2000). The river Pinka exhibits sound hydro-morphological sections with near natural riparian vegetation and minor land use, as well as highly impacted sections in terms of vegetation cover, in total twelve urban/settlement areas, river geometry and continuity. Substrates are dominated by late tertiary sedimentary rocks and, to a lesser extent, by volcanic rocks (Wimmer et al., 2012). The main hydrological characteristics are summarized in Table 1.

While the entire Austrian river stretch (source to distance from source $62.55 \mathrm{~km}$ (DFS 62.55)) was the object of investigations, the river stretch between DFS 30.00 and DFS 50.00 was chosen for detailed analysis. This river stretch has no remarkable tributaries and a rather uniform flow direction. Discharge records were available at four gauges situated at DFS 12.45, 37.75, 58.65 and 62.55 (Fig. 1). For describing the meteorological situation, records of air temperature (AT), hours of sunshine, global radiation and precipitation at two near-by stations Kleinzicken (1.5 km to DFS 52.00) and Bad Tatzmannsdorf (3 km to DFS 38.00) were used.

\subsection{Vegetation-shading index (VSI)}

Vegetation mapping was performed based on aerial photographs and field measurements. Following DeWalle (2010), Moore et al. (2005) and Sridhar et al. (2004) we considered a buffer zone of $50 \mathrm{~m}$ from the centreline of the river as being relevant for stream temperature. From aerial photographs we delineated polygons that were homogeneous in terms of land use, vegetation cover and vegetation composition. The polygons were refined by evidence from intensive site visits, where also vegetation height in the form of Koch classes $(<5,-10,-20,>20 \mathrm{~m})$, and vegetation density clustered as Braun Blanquet $(<5,-25,-50,-5$, $-100 \%)$, see (Traxler, 1997), were recorded. In a following step, the results were transferred from area to point information, using the Arc View sampling extension "TTools" (Kasper and Boyd, 2002). During the process, the information was assigned to cross-sections, every $50 \mathrm{~m}$ along the river, perpendicular to the river axis. Ten points were generated every $5 \mathrm{~m}$ orographically left and right from the centerline, with vegetation parameters being assigned at each of these cross-sections.

For each $50 \mathrm{~m}$ cross-section, VSI was calculated that integrates the parameters vegetation height $\left(h_{R}\right)$, vegetation width $(w)$, and vegetation density $(d)$, as these parameters were found to influence water temperature (WT) most (DeWalle, 2010; Holzapfel et al., 2013). For the VSI of a northwards or southwards flowing river, all vegetation parameters were calculated as mean values of the orographic left and right river bank. When the river was flowing eastwards, the orographically right bank was used for calculations, and when it was flowing westwards the orographically left bank was used. Based on this guideline the VSI is computed as:

$$
\mathrm{VSI}=\left(\frac{h_{R}}{h_{\max }}+\frac{w}{w_{\max }}+\frac{d}{d_{\max }}\right) \div 3
$$


Table 1. Hydrological data describing different sites along the river Pinka. Abbreviations: DFS = distance from source, $M Q=m e a n$ discharge; WT = water temperature measuring point.

\begin{tabular}{|c|c|c|c|c|c|c|c|c|c|c|}
\hline $\begin{array}{l}\text { DFS } \\
(\mathrm{km})\end{array}$ & MQ $\left(\mathrm{m}^{3} / \mathrm{s}\right)$ & $\begin{array}{l}\text { Flow } \\
\text { direction (-) }\end{array}$ & $\begin{array}{l}\text { Catchment } \\
\left(\mathrm{km}^{2}\right)\end{array}$ & $\begin{array}{l}\text { Strahler order } \\
\text { number }(-)\end{array}$ & $\begin{array}{l}\text { Altitude } \\
\text { (m.a.s.l.) }\end{array}$ & $\begin{array}{l}\text { Gradient } \\
(\% o)\end{array}$ & $\begin{array}{l}\text { River } \\
\text { width (m) }\end{array}$ & $\begin{array}{l}\text { Distance from } \\
\text { last WT }(\mathrm{km})\end{array}$ & $\begin{array}{l}\text { Minutes from } \\
\text { last WT (min) }\end{array}$ & $\begin{array}{l}\text { Average time } \\
500 \mathrm{~m}(\mathrm{~min})\end{array}$ \\
\hline 2.3 & & East & & 2 & & & 2 & & & \\
\hline 10.97 & 0.4 & South & 36 & 3 & 559 & 0.036 & 5 & & & \\
\hline 15.28 & 1.0 & South & & 4 & 515 & 0.014 & 8 & 4.49 & 116 & 12 \\
\hline 19.79 & 1.0 & South & 134 & 5 & 414 & 0.008 & 10 & 4.51 & 140 & 14 \\
\hline 30.69 & 1.0 & North & & 5 & 342 & 0.004 & 13 & 10.9 & 336 & 15 \\
\hline 34.86 & 1.2 & East & & 5 & 319 & 0.006 & 7 & 4.17 & 132 & 13 \\
\hline 37.23 & 1.2 & East & 172 & 5 & 306 & 0.004 & 7 & 2.37 & 60 & 12 \\
\hline 39.01 & 1.2 & South & & 5 & 299 & 0.004 & 7 & 1.78 & 47 & 9 \\
\hline 44.26 & 1.2 & East & & 5 & 279 & 0.002 & 10 & 5.25 & 235 & 21 \\
\hline 45.39 & 1.2 & East & & 5 & 276 & 0.003 & 10 & 1.13 & 55 & 14 \\
\hline 45.55 & 1.2 & East & & 5 & 275 & 0.003 & 10 & 0.16 & 8 & 8 \\
\hline 48.4 & 1.2 & South & & 5 & 266 & 0.004 & 10 & 2.85 & 125 & 18 \\
\hline 53.04 & 1.2 & North & & 5 & 257 & 0.001 & 8 & 4.64 & 224 & 22 \\
\hline 53.22 & 2.0 & East & & 6 & 256 & 0.001 & 8 & 0.18 & 11 & 11 \\
\hline 55.09 & 2.0 & East & & 6 & 249 & 0.002 & 6 & 1.87 & 76 & 15 \\
\hline 58.79 & 2.0 & East & 417 & 6 & 244 & 0.001 & 6 & 3.7 & 139 & 17 \\
\hline 61.51 & 2.0 & North & 664 & 6 & 240 & 0.002 & 5 & 2.72 & 119 & 17 \\
\hline
\end{tabular}

where $h_{R}(\%)$, relative vegetation height, weighted ratio of vegetation height and river width, which is calculated as:

$$
\begin{aligned}
\text { if } & \frac{\text { vegetation height } * 100}{\text { river width } * 1.5} \leq 100 ; \text { then } h_{R} \\
= & \frac{\text { vegetation height } * 100}{\text { river width } * 1.5} ; \text { else } h_{R}=100 .
\end{aligned}
$$

Note: That multiplication of the river width with 1.5 is due to the fact that a tree height of $15 \mathrm{~m}$ generates, at this geographic position, a shade length of $10 \mathrm{~m}$, from 10 a.m. to 2 p.m., and can fully shade the present river width. $h_{\max }$ $(\%)$ - maximum vegetation height $(=100 \%) ; w(\mathrm{~m})$ - width of the woody riparian vegetation buffer; $w_{\max }(\mathrm{m})$ - maximum vegetation width, $(=50 \mathrm{~m}$, as this is defined as maximum width influencing the WT); $d(\%)$ - vegetation density= vegetation cover related to ground area; $d_{\max }(\%)$ - maximum vegetation density $(=100 \%)$.

The obtained VSI values range between 0 (no vegetation) and 1 (full vegetation). Because of river flow, WT at a river site will depend on the upstream situation but it is unclear at what section length vegetation will have most influence. We therefore calculated mean VSI values for upstream sections of WT measurement points of various lengths, ranging between $50 \mathrm{~m}$ and $10000 \mathrm{~m}\left(\mathrm{VSI}_{50}\right.$ to $\left.\mathrm{VSI}_{10000}\right)$. For validating these VSI indices we used the Global Site Factor (GSF), computed from hemispherical photographs (Rich et al., 1999) that were taken at 43 sites between DSF 0.05 and DFS 62.81 .

\subsection{Selection of the study period}

Heatwave events were of particular interest in this project. Hence, the analysis was carried out for the summer of 2013
(1 June-31 August) when record temperatures of $40.5^{\circ} \mathrm{C}$ were measured by public meteorological stations in this region. The days were classified into non-heatwave periods (NK), heatwave periods $(\mathrm{K})$ and extreme heatwave days $(\mathrm{K}+)$ following Kyselý et al. (2000). According to this definition, a heatwave period $(\mathrm{K})$ is characterised by at least three subsequent days with maximum air temperatures $\left(\mathrm{AT}_{\max }\right) \geq 30^{\circ} \mathrm{C}$ and continues until the $\mathrm{AT}_{\text {max }}$ drops below $25^{\circ} \mathrm{C}$ or the mean $\mathrm{AT}_{\text {max }}$ of the period is below $30^{\circ} \mathrm{C}$. Extreme heatwave days $(\mathrm{K}+)$ additionally have clear sky conditions ( $\geq 80 \%$ of possible sun hours - defined by (MeteoSchweiz)), precipitations below $1 \mathrm{~mm} /$ day and discharges of a maximum of $75 \%$ of the mean discharge (used as a threshold for low flow conditions).

For comparison of sunny and cloudy days additionally, single consecutive days with clear sky conditions $(\geq 80 \%$ of possible sun hours) and cloudy conditions $(\leq 50 \%$ of possible sun hours), with no intermediate rain, were selected (Tab. 2).

\subsection{Measurement and analysis of water temperature}

Data sets concerning river WT were collected at a spatially distributed network of 17 HOBO Pendant Temperature Data Loggers 8K*UA-002-08 along the river Pinka (Tab. 1 and Fig. 1). Data was sampled hourly, from June 2013 until August 2013. We analyse the relationships between water temperature along the river with meteorological variables and with the VSI by means of Spearman's rank correlation $\left(r_{s}\right)$. In addition, we analysed the relationships between impotent parameters by linear regression.

\subsection{Numerical water temperature model}

In order to gain a better understanding of the influence of riparian shading on the change in $\mathrm{WT}_{\max }$ the energy balance 
$\Phi_{\text {total }}$ along the river was calculated using the model HEAT SOURCE version 9 (Boyd and Kasper, 2003). The model is based on the following energy balance equation:

$$
\begin{aligned}
\Phi_{\text {Total }} & =\Phi_{\text {Evaporation }}+\Phi_{\text {Convection }}+\Phi_{\text {Longwave }}+\Phi_{\text {Solar }} \\
& +\Phi_{\text {Conduction }}
\end{aligned}
$$

where $\Phi_{\text {Total }}$ is the energy balance, $\Phi_{\text {Evaporation }}$ the evaporation flux, $\Phi_{\text {Convection }}$ the convection flux, $\Phi_{\text {Longwave }}$ the long wave radiation balance (all referring to the stream surface), $\Phi_{\text {Solar }}$ is the short wave energy, which is absorbed by the water column,

Table 2. Two 5-day periods with consecutive days of clear sky and cloudy conditions and the according maximum air temperatures $\left(\mathrm{AT}_{\max }\right)$. Abbreviations: $\mathrm{DFS}=$ distance from source; $\mathrm{NK}=$ nonheatwave period; $\mathrm{K}=$ heat wave period.

\begin{tabular}{lllll}
\hline Date & $\begin{array}{l}\text { \% possible } \\
\text { sun }\end{array}$ & $\begin{array}{l}\text { Discharge } \\
(\mathrm{DFS} \mathrm{37.75)}\end{array}$ & $\begin{array}{l}\mathrm{AT}_{\max } \\
\left({ }^{\circ} \mathrm{C}\right)\end{array}$ & Period \\
\hline 13.07 .2013 & 58 & 0.69 & 24.8 & $\mathrm{NK}$ \\
14.07 .2013 & 72 & 0.68 & 26.4 & $\mathrm{NK}$ \\
15.07 .2013 & 28 & 0.68 & 25.5 & $\mathrm{NK}$ \\
16.07 .2013 & 92 & 0.6 & 26 & $\mathrm{NK}$ \\
17.07 .2013 & 92 & 0.63 & 28.6 & $\mathrm{NK}$ \\
29.07 .2013 & 86 & 0.44 & 36.9 & $\mathrm{~K}$ \\
30.07 .2013 & 48 & 0.43 & 27.9 & $\mathrm{~K}$ \\
31.07 .2013 & 36 & 0.43 & 28.7 & $\mathrm{~K}$ \\
01.08 .2013 & 82 & 0.42 & 30.6 & $\mathrm{~K}$ \\
02.08 .2013 & 92 & 0.41 & 34.3 & $\mathrm{~K}$ \\
\hline
\end{tabular}

and $\Phi_{\text {Conduction }}$ the conduction flux. The model was validated for use in the research area in a study by Trimmel et al. (2016).

WT increase $(\Delta T)$ caused by energy gains was calculated by using the following formula:

$$
\Delta T=\frac{Q}{c * m},
$$

where $Q$ is the heat energy input $\left(\mathrm{W} / \mathrm{m}^{2}\right)$ into the river, $m$ the water mass $(\mathrm{kg})$ and $c$ the specific heating capacity of water.

Possible ground water $(\mathrm{GW})$ influences were analysed in the area between DFS 37.75 (38) to DFS 58.65, by considering the discharge volume (WV) of the tributaries Zickenbach (Zick), Teichbach (Teich) and Gerenthbach (Ger). The WT of these assumed inflows was then incorporated, and the resulting $\mathrm{WT}\left(\mathrm{WT}_{R}\right)$ of the river Pinka was estimated using the formula as follows:

$$
\begin{aligned}
\mathrm{WT}_{R} & =\% \mathrm{WV}_{38} * \mathrm{WT}_{38}+\% \mathrm{WV}_{\text {Zick }} * \mathrm{WT}_{\text {Zick }} \\
& +\% \mathrm{WV}_{\text {Teich }} * \mathrm{WT}_{\text {Teich }}+\% \mathrm{WV}_{\mathrm{Ger}} * \mathrm{WT}_{\mathrm{Ger}} \\
& +\% \mathrm{WV}_{\mathrm{GW}} * \mathrm{WT}_{\mathrm{GW}},
\end{aligned}
$$

where $\% \mathrm{WV}_{38}=$ percentage of the water volume at DFS 37.75 .

\section{Results}

\subsection{Riparian vegetation}

In the upper reaches of the river Pinka (from source to DFS 20.00), the mean $\mathrm{VSI}_{50}$ was 0.69 , which reveals a high level of shading, and points to areas of rather high, wide and dense riparian vegetation, often featured by commercial forests (Fig. 2a). Downstream of DFS 20.00, the river flows through
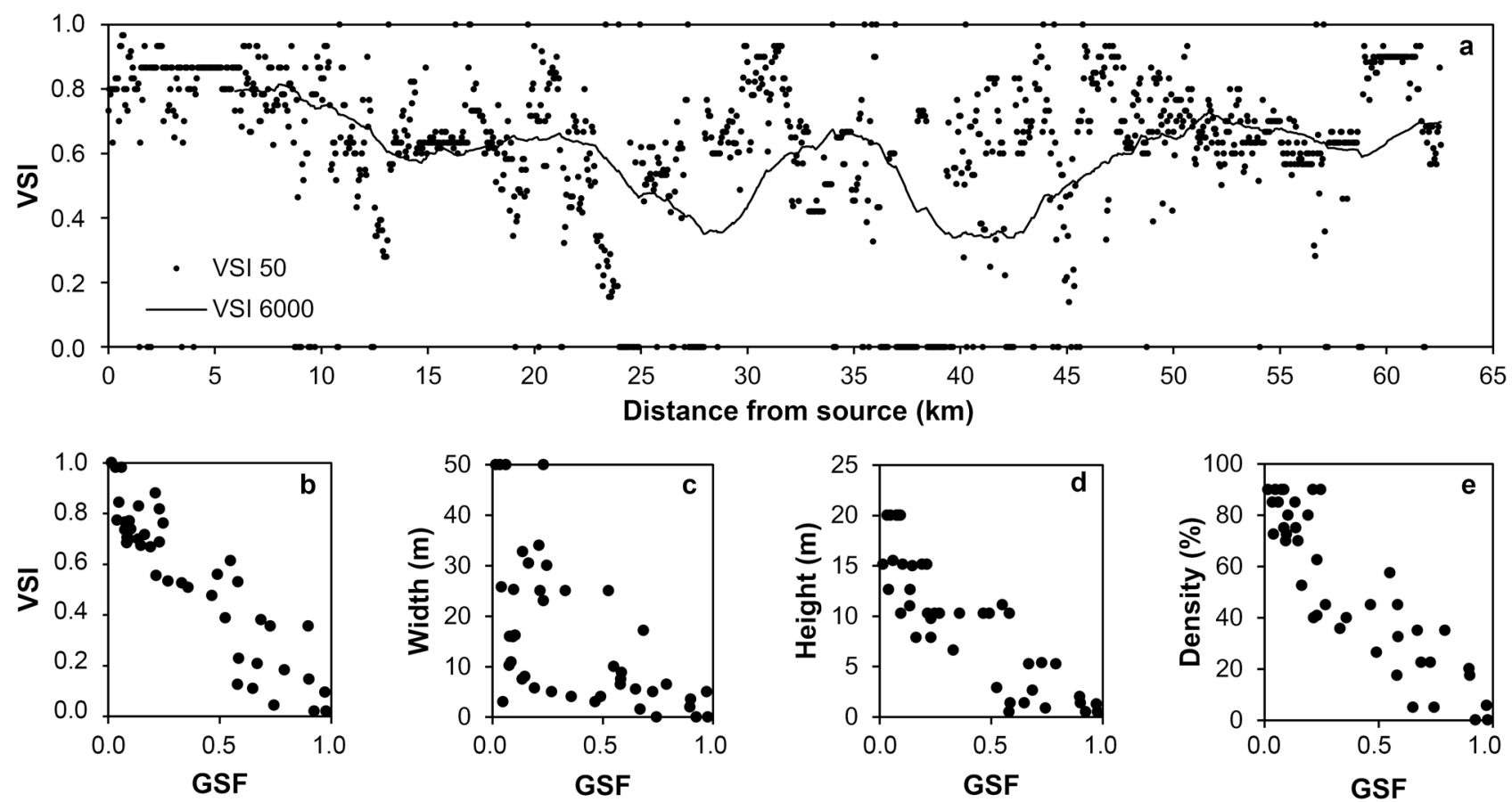

Fig. 2. (a) Distribution of the longitudinal vegetation-shading index (VSI) values of the river Pinka, referring $50 \mathrm{~m}$ sections upstream of the water temperature measuring points, as well as $6000 \mathrm{~m}$ sections. The scatter plots show the ratio of Global Site Factors (GSF) and VSI ${ }_{50} \mathrm{~s}$ (b), as well as the vegetation parameters width (c), height (d) and density (e). 
settlement areas and agricultural lands. The VSIs for these middle and lower reaches were more diverse, $16 \%$ of the river stretch showed a $\mathrm{VSI}_{50}$ below 0.2 and $62 \%$ had a $\mathrm{VSI}_{50}$ above 0.6. Particularly notable was the very low mean $\mathrm{VSI}_{50}$ of 0.15 from DFS 37.00 to DFS 39.65. This section had almost no riparian vegetation and consequently no vegetation shading effect (Fig. 2). In terms of longer stretches, the $\mathrm{VSI}_{6000}$ showed two deep depressions between DFS 20.00 and DFS 50.00, dropping down to 0.35 and 0.34 .

The VSI values were compared with GSF values from the hemispherical photographs. The correlation coefficient $\left(r_{s}\right)$ between GSF and VSI (Fig. 2b) was 0.8 during times of highest sun elevation, and 0.9 for the GSF over the whole day $(p<0.01)$. The high correlation coefficients underline the appropriateness of the newly proposed VSI for characterising vegetation shading. Vegetation parameters height, width and density (Fig. 2c-e) cannot reach higher correlations.

\subsection{Hydro-meteorological conditions}

Figure 3 shows the hydro-meteorological conditions of summer 2013 for the study area. According to the Kyselý classification the summer of 2013 is characterised by two heatwave periods (K): from 17th June 2013 to 23rd June 2013, and from 23rd July 2013 to 9th August 2013, which amounted, in total, to 25 days (Fig. 3a). These two periods included 16 clear sky days and 20 days without any precipitation. Extreme heatwave days $(\mathrm{K}+)$ were defined on $2 \mathrm{nd}, 3 \mathrm{rd}$, 6th, 7th and 8th August 2013 additionally taking into account days with a discharge of less than $75 \%$ of the mean flow.

The temporal patterns of precipitation and discharges at DSF 12.45 and $37.75 \mathrm{~km}$ are presented in Figure $3 \mathrm{~b}$. There were only few and mostly minor precipitation events during the summer of 2013. Consequently, the discharges steadily decreased and reached a minimum at 3rd August 2013, corresponding to a low flow event. WT shows temporal development that is reverse to the discharge (Fig. 3c) as would be expected.

Figure 4 shows the distribution of WT along the river. On average, daily mean water temperatures $\left(\mathrm{WT}_{\text {mean }}\right)$ increased, from about $9.4^{\circ} \mathrm{C}$ to $18.7^{\circ} \mathrm{C}, \mathrm{WT}_{\max }$ increased from $10.4^{\circ} \mathrm{C}$ to $20.4^{\circ} \mathrm{C}$. During heatwave periods $(\mathrm{K})$, average $\mathrm{WT}_{\max }$ increased much stronger, up to $24.4^{\circ} \mathrm{C}$ at DFS 62.55, and even to $26^{\circ} \mathrm{C}$ during the extreme heatwave days $(\mathrm{K}+)$. However, there was no steady increase in WT from source to DFS 62.55. Especially noticeable is the decrease of $\mathrm{WT}_{\max }$ in the extreme heatwave days $(\mathrm{K}+)$ of $4.7^{\circ} \mathrm{C}$, from DFS 39.01 to DFS 53.22. This decrease was much lower during the nonheatwave period (NK) it was only $3{ }^{\circ} \mathrm{C}$. Such increases and decreases were mainly observed for $\mathrm{WT}_{\max }$ and daily water temperature range ( $\mathrm{WT}_{\text {range }}$ ), whereas variations were small in $\mathrm{WT}_{\text {mean }}$ (Fig. 4c,d). The highest WT values in all periods were measured at DFS 39.01; a low shaded area, where at extreme heatwave days $(\mathrm{K}+)$, on average, values of $\mathrm{WT}_{\text {range }}=6.9^{\circ} \mathrm{C}$ and $\mathrm{WT}_{\max }=28.2^{\circ} \mathrm{C}$, were reached. This issue will further be explored in a later section.

For the middle reaches (DFS 30.00 to DFS 50.00), which represent conditions without considerable inflows, we assessed the dependence of WT on meteorological parameters. Spearman correlations coefficients $\left(r_{s}\right)$ point to a strong relationship between $\mathrm{WT}_{\max }$ and $\mathrm{AT}_{\text {max }}$, with values between 0.85 and $0.94(p<0.01)$. In addition, we observed significant, but lower correlations (about 0.5) with global radiation, and with sun hours as well.

\subsection{Effects of VSI section length on water temperature}

Figure 5 illustrates the VSI as a function of $\mathrm{WT}_{\max }$, $\mathrm{WT}_{\text {range }}, \mathrm{WT}_{\text {mean }}$ and daily minimum water temperatures $\left(\mathrm{WT}_{\min }\right)$, during the extreme heatwave days $(\mathrm{K}+)$ in the middle reaches (DFS 30.00 to DFS 50.00), for the different river section lengths from $50 \mathrm{~m}$ and up to $10000 \mathrm{~m}$ upstream of the WT measuring points. Mostly negative correlations are observed, illustrating that a higher VSI is related with lower WT. The strengths of the correlation strongly depended on the section lengths and the WT parameters. $\mathrm{WT}_{\max }$ and $\mathrm{WT}_{\text {range }}$ were the most highly correlated parameters (Fig. 5). Correlations for these parameters increased when increasing the considered river section length for VSI calculation from $50 \mathrm{~m}$ to $6000 \mathrm{~m}$, from -0.34 to -0.73 for $\mathrm{WT}_{\text {range }}$, and from -0.5 to -0.82 for $\mathrm{WT}_{\max }$. However, larger river section lengths again led to a decrease of the correlations. The calculated VSIs for river section lengths from $4000 \mathrm{~m}$ to $7000 \mathrm{~m}$, showed the highest correlations with values of about -0.7 . The statistically best performing VSI value was calculated for a section length of $6000 \mathrm{~m}$ with -0.82 for $\mathrm{WT}_{\max }$ and -0.73 for $\mathrm{WT}_{\text {range }}$. Consequently, $\mathrm{VSI}_{6000}$ were considered as most representative in this study. In contrast, much lower correlations were observed for $\mathrm{WT}_{\text {min }}$ and $\mathrm{WT}_{\text {mean }}$ with a correlation coefficient of $-0.05\left(\mathrm{WT}_{\min }\right)$ and $-0.42\left(\mathrm{WT}_{\text {mean }}\right)$ for $\mathrm{VSI}_{6000}$. They represent more the night conditions; hence, they do not depend so much on radiation and shading effects. We will therefore focus on $\mathrm{WT}_{\max }$ and $\mathrm{WT}_{\text {range }}$ in the subsequent analyses.

Similar relationships were also observed between $\mathrm{WT}_{\max }$ and selected vegetation parameters with correlations coefficients $\left(r_{s}\right)$ between -0.77 (vegetation width) to -0.84 (vegetation density). Vegetation height showed a lower correlation with a coefficient of -0.55 .

\subsection{Impact of shading and cloudiness on water temperature}

Observing successive days with differing cloud cover conditions (Tab. 2), but same discharges, $\mathrm{WT}_{\max }$ reacted in different ways. During the heatwave period (K) greatest increases and decreases in WT could be seen from DFS 34.86 to DFS 53.22 (Fig. 6a). On the 29th July 2013, a clear day, $\mathrm{WT}_{\text {max }}$ rose from DFS 34.86 to DFS 39.01 , by $3.9^{\circ} \mathrm{C}$ to $\mathrm{WT}_{\max }$ values of $28.8^{\circ} \mathrm{C}$. The river morphology of this stretch is heavily impacted by river regulations and low amount of riparian vegetation which results in a mean $\mathrm{VSI}_{50}$ of 0.31 . The $14.21 \mathrm{~km}$ long river stretch downstream of DFS 39.01, has a more natural appearance with dense riparian vegetation buffers (mean $\mathrm{VSI}_{50}=0.61$ ). Henceforth, $\mathrm{WT}_{\max }$ decreased from $28.8^{\circ} \mathrm{C}$ down to $23.8^{\circ} \mathrm{C}$. On the 30th July 2013 , a mean cloudy day, $\mathrm{WT}_{\max }$ at DFS 39.01 had a lower peak of $25.1^{\circ} \mathrm{C}$ with lower warming $\left(1.1^{\circ} \mathrm{C}\right)$ and cooling $\left(2.6^{\circ} \mathrm{C}\right)$ gradients. These gradients decreased even more on the 31 st July 2013 , a cloudy 

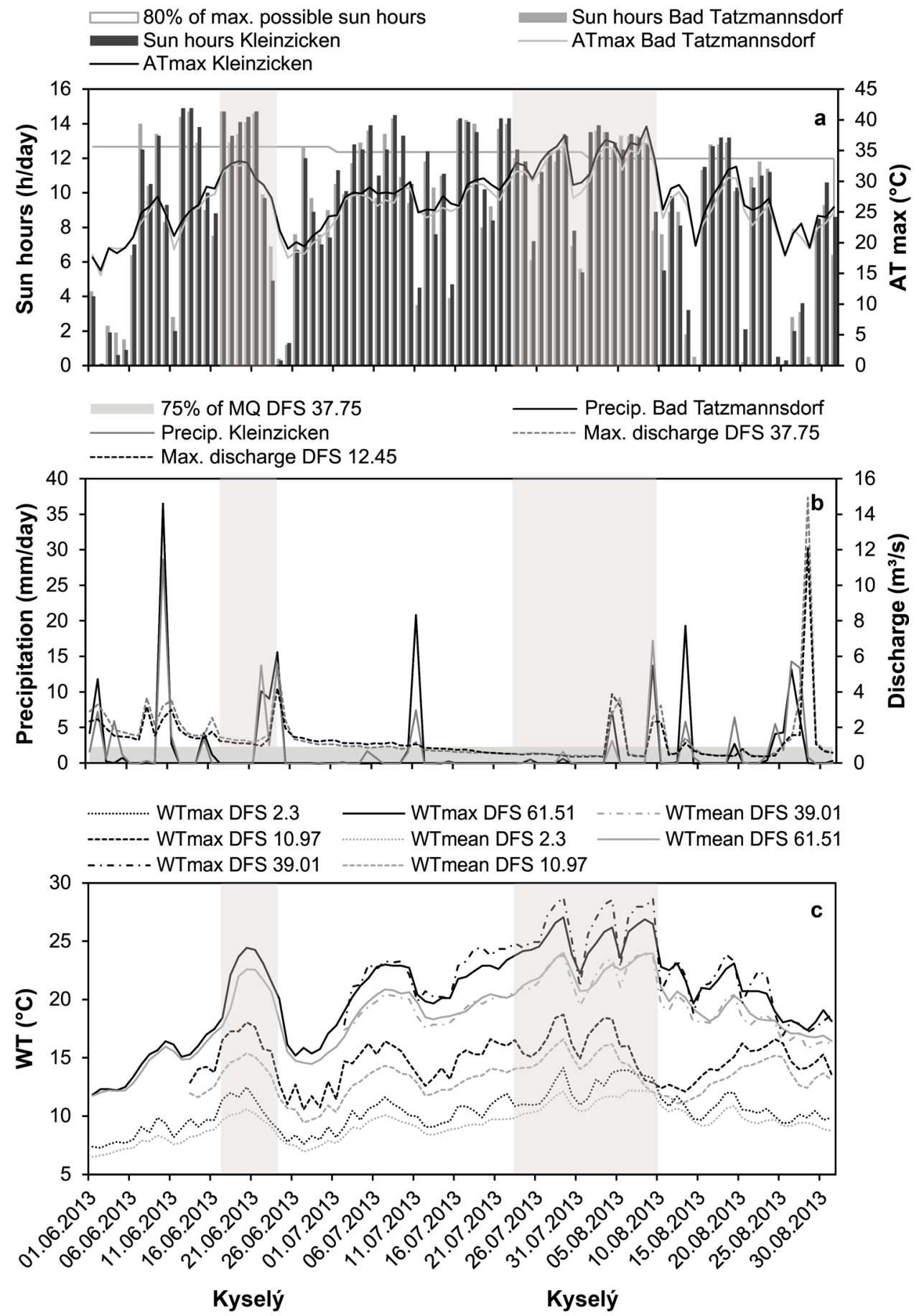

Fig. 3. Hydro-meteorological characteristics of the summer of 2013 at the Pinka region: (a) daily maximum air temperature (AT $\mathrm{T}_{\max }$ ), and sun hours per day measured at the climate stations Kleinzicken and Bad Tatzmannsdorf, (b) daily precipitation (precip.) at the same climate stations, and the resulting discharges at two gauges (DFS 12.45 and 37.75), and (c) daily maximum and mean water temperatures (WT max and WT mean) at selected sites along the river Pinka (DFS = distance from source). The heat wave periods (Kyselý) are shaded in grey.

day. On 1st August 2013, and 2nd August 2013, two clear days, $\mathrm{WT}_{\max }$ rose back to precloud conditions. Figure $6 \mathrm{~b}$ shows the same tendencies in the non-heatwave periods (NK). Daily $\mathrm{WT}_{\min }$ remained stable during both periods. Since no precipitation occurred during these periods, and discharge volume remained at the same level, we anticipated that the influence of ground water on WT is similar on all days. Consequently the key element for changing WTs is the incident solar radiation influenced by the appearance of riparian vegetation.

\subsection{Daily variations of water temperature}

Considering the $\mathrm{VSI}_{6000}$ of the river sections, there was a clear difference in WT behaviour. In the extreme heatwave 

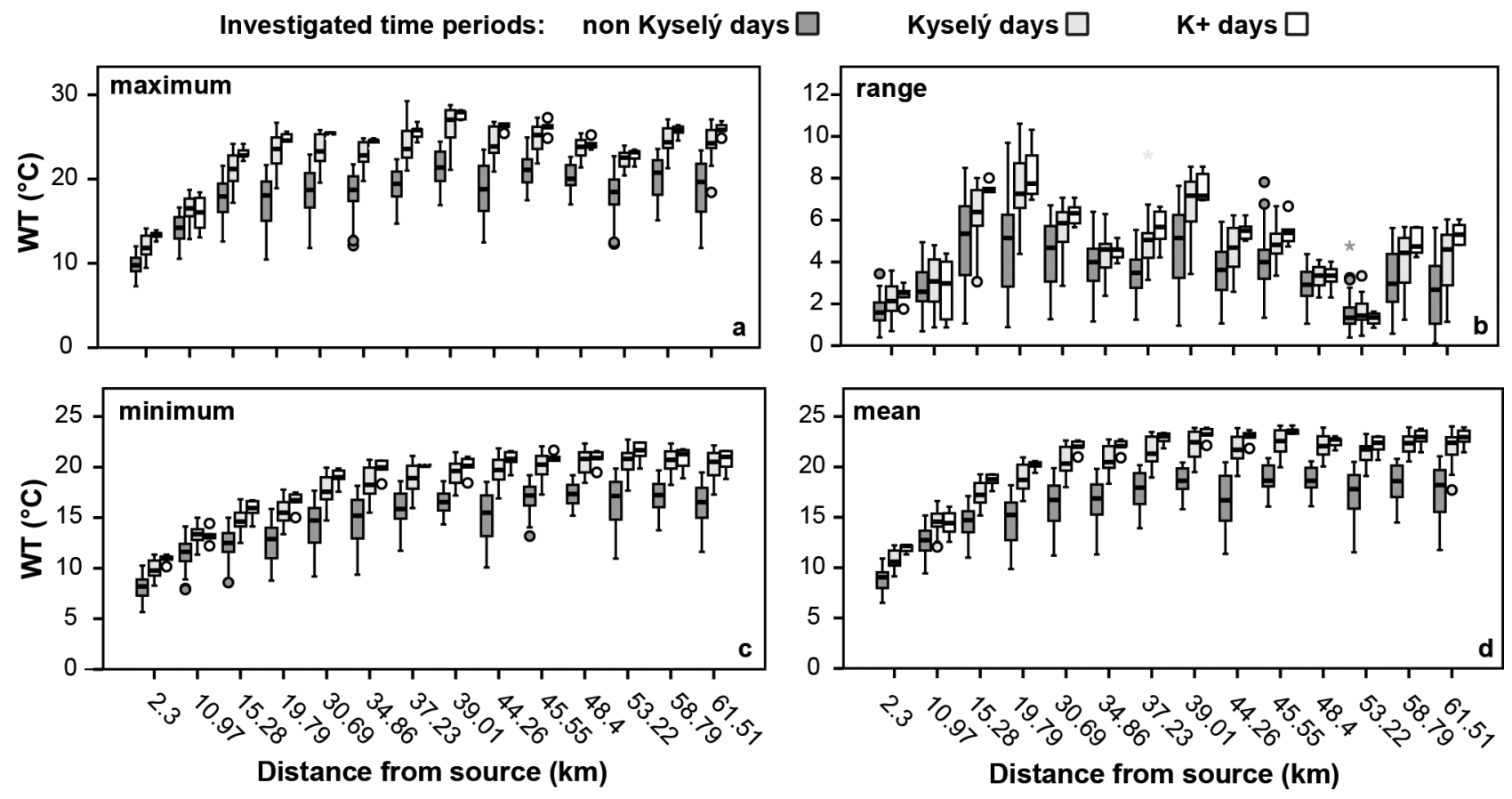

Fig. 4. Distribution of water temperature (WT) at the different WT stations along the river Pinka during summer 2013, for periods of nonheatwave periods (non-Kyselý), heatwave periods (Kyselý) and extreme heatwave days (Kyselý+) respectively. With (a) WT maximum, (b) WT ranges, (c) WT minimum and (d) WT mean.

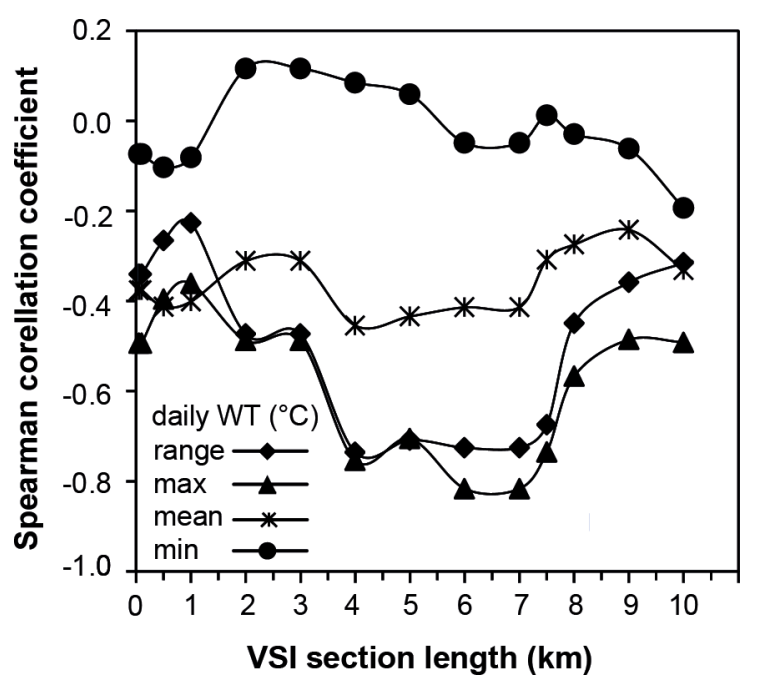

Fig. 5. Absolute spearman correlation coefficients of the vegetationshading index (VSI) to the daily water temperature (WT) parameters, related to the specific VSI section lengths. The data from WT stations is related to distance from source (DFS) 30.00 and DFS 50.00 on extreme heatwave $(\mathrm{K}+)$ days.

days $(\mathrm{K}+)$ a $\mathrm{WT}_{\max }$ of $28.1{ }^{\circ} \mathrm{C}$ was reached earliest at $1 \mathrm{p} . \mathrm{m}$. at DFS 39.01, a very sparsely shaded section ( $\mathrm{VSI}_{6000} 0.37$ ). Opposed the most shaded areas $\left(\mathrm{VSI}_{6000}\right.$ above 0.6$)$ reached mean $\mathrm{WT}_{\max }$ of $23.6^{\circ} \mathrm{C}$ from 6 p.m. to 9 p.m. (Fig. 7). The $\mathrm{WT}_{\text {range }}$ amounted to $7.6^{\circ} \mathrm{C}$ for the unshaded, to an average of $5.3^{\circ} \mathrm{C}$ for medium shaded and to an average of $3.6^{\circ} \mathrm{C}$ for highly shaded upstream conditions. In the heatwave and nonheatwave periods, the temporal curve progression was quite similar, except that the entire curve had a temperature offset. In the extreme heatwave days $(\mathrm{K}+)$ mean $\mathrm{WT}_{\max }$ was $6.7^{\circ} \mathrm{C}$ higher than in non-heatwave periods (NK).

\subsection{Correlation of water and air temperature}

$\mathrm{WT}_{\max }$ and $\mathrm{AT}_{\max }$ are highly correlated. Figure 8a shows scatter-plots for selected WT stations. The slopes of the $\mathrm{WT}_{\max }-\mathrm{AT}_{\max }$ regression line is low in the upstream reaches, whereas the slopes much higher at locations between DFS 30.69 and DFS 61.51. However, the slopes of the regression lines also depend on the VSI value (Fig. 8b). The analysis of the interrelationship between different slopes of the $\mathrm{WT}_{\max }{ }^{-}$ $-\mathrm{AT}_{\max }$ regression line and the riparian vegetation (Fig. 8c-f) revealed that steeper slopes indicate a lower VSI and therewith a higher impact of the AT on the WT. Considering these correlations, Table 3 shows the calculated WT changes due to an AT increase of $2^{\circ} \mathrm{C}$.

\subsection{Field data validation by a numerical river temperature model}

The energy balance of two sites with different vegetation structures (full vegetation DFS 46.00/no vegetation DFS 39.01), was simulated by HEAT SOURCE, using formula (3). Energy balance never dropped below $0 \mathrm{~W} / \mathrm{m}^{2}$ during the daytime in both cases, independent of cloudiness (Fig. 9). At the time of highest sun elevation on a clear day, the maximum values of the energy balance varied from $194 \mathrm{~W} / \mathrm{m}^{2}$ (Fig. 9a), for areas without vegetation, to $35 \mathrm{~W} / \mathrm{m}^{2}$ (Fig. 9b) for fully vegetated areas. Vegetation structures had less impact during cloudy conditions with a difference of just $39 \mathrm{~W} / \mathrm{m}^{2}$. 

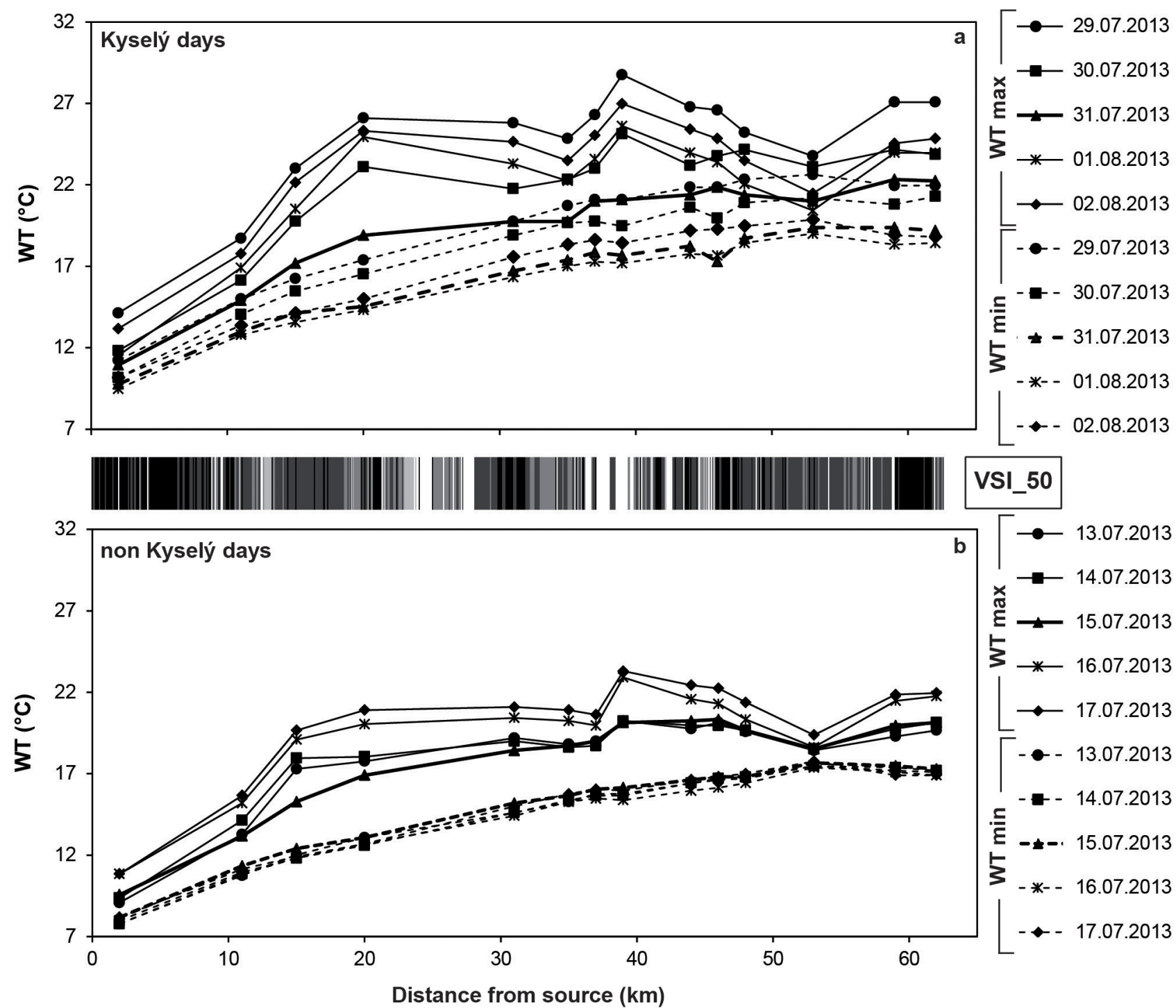

Fig. 6. Distribution of the longitudinal vegetation-shading index (VSI 50) and water temperature (WT) values of two 5-day periods with differing cloudiness conditions. Periods describe (a) heatwave (Kyselý) and (b) non-heatwave (non-Kyselý) conditions.

The calculated energy gains on a $1 \mathrm{~km}$ long river stretch, with dimensions such as DFS 39.01, and no riparian vegetation, increased river WT by $0.4{ }^{\circ} \mathrm{C}$ (Formula (4)). This results in an increase of $3.3^{\circ} \mathrm{C}$ for a river section of $9 \mathrm{~km}$. Under the same conditions, but with less energy due to dense vegetation, the WT increased just by $0.1^{\circ} \mathrm{C}$. Consequently, other cooling influences could have a stronger impact in shaded areas.

Observing the time period with the lowest discharge values, DFS 39.01 amounted to $60 \%$ of the water mass achieved on DFS 58.79. Above ground tributaries added another $24 \%$ of water mass. The WT of the Zickenbach, the biggest tributary showed no significant differences in WT in comparison to the river Pinka. Therefore, $16 \%$ of the water mass was ground water and assumed to be the reason for the WT decrease. Ground water temperatures from nearby stations showed mean values of $12{ }^{\circ} \mathrm{C}$. Formula (5) was used to calculate the WT of $1 \mathrm{~m}^{3}$ water along the $19.78 \mathrm{~km}$ long river stretch. WT decreases of $3.6^{\circ} \mathrm{C}$ were calculated whereas the observed reduction of $\mathrm{WT}_{\max }$ was $5^{\circ} \mathrm{C}$.

\section{Discussion}

\subsection{VSI and its spatial scale in terms of water temperature}

In the present study, VSI was calculated as an integral parameter, taking into account vegetation height, width and density, whereby all three have a verifiable impact on the solar radiation situation input on a stream surface. These are the parameters most commonly studied concerning global radiation reduction (Zwieniecki and Newton, 1999; DeWalle, 2010; Sridhar et al., 2004) but there are no clear results concerning the ranked importance of these. The VSI results in a significant correlation which had the same or even better correlation coefficients with WT as the 
G. Kalny et al.: Knowl. Manag. Aquat. Ecosyst. 2017, 418, 5
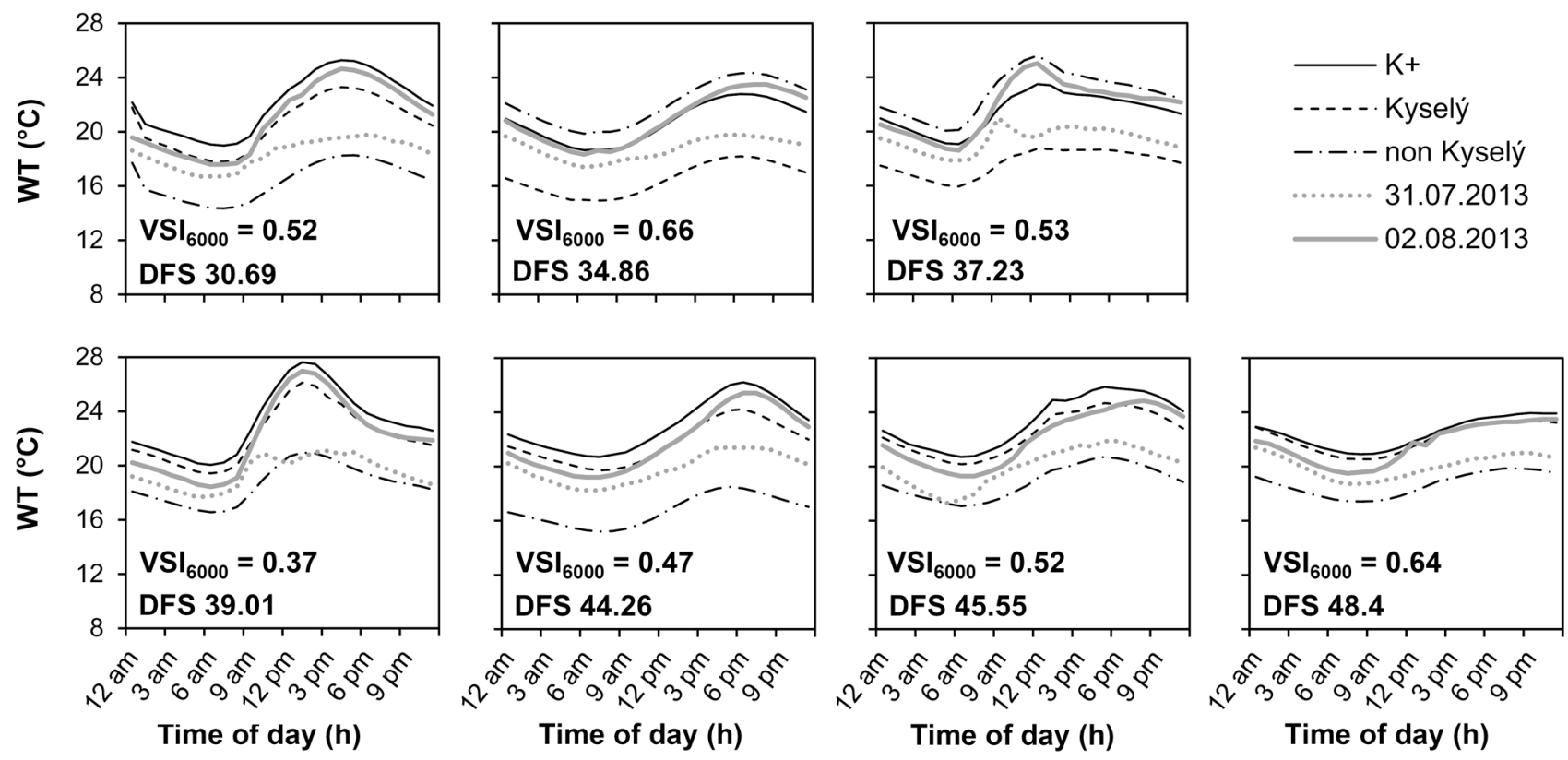

Fig. 7. Overview of the mean daily water temperature (WT) variations from non-heat wave (non-Kyselý), heat wave (Kyselý) and extreme heat days $(\mathrm{K}+)$, as well as mean WT variations for a cloudy day (31.7.2013) and a clear sky day (2.8.2013) at seven selected WT stations between distance from source (DFS) 30.00 and DFS 50.00.
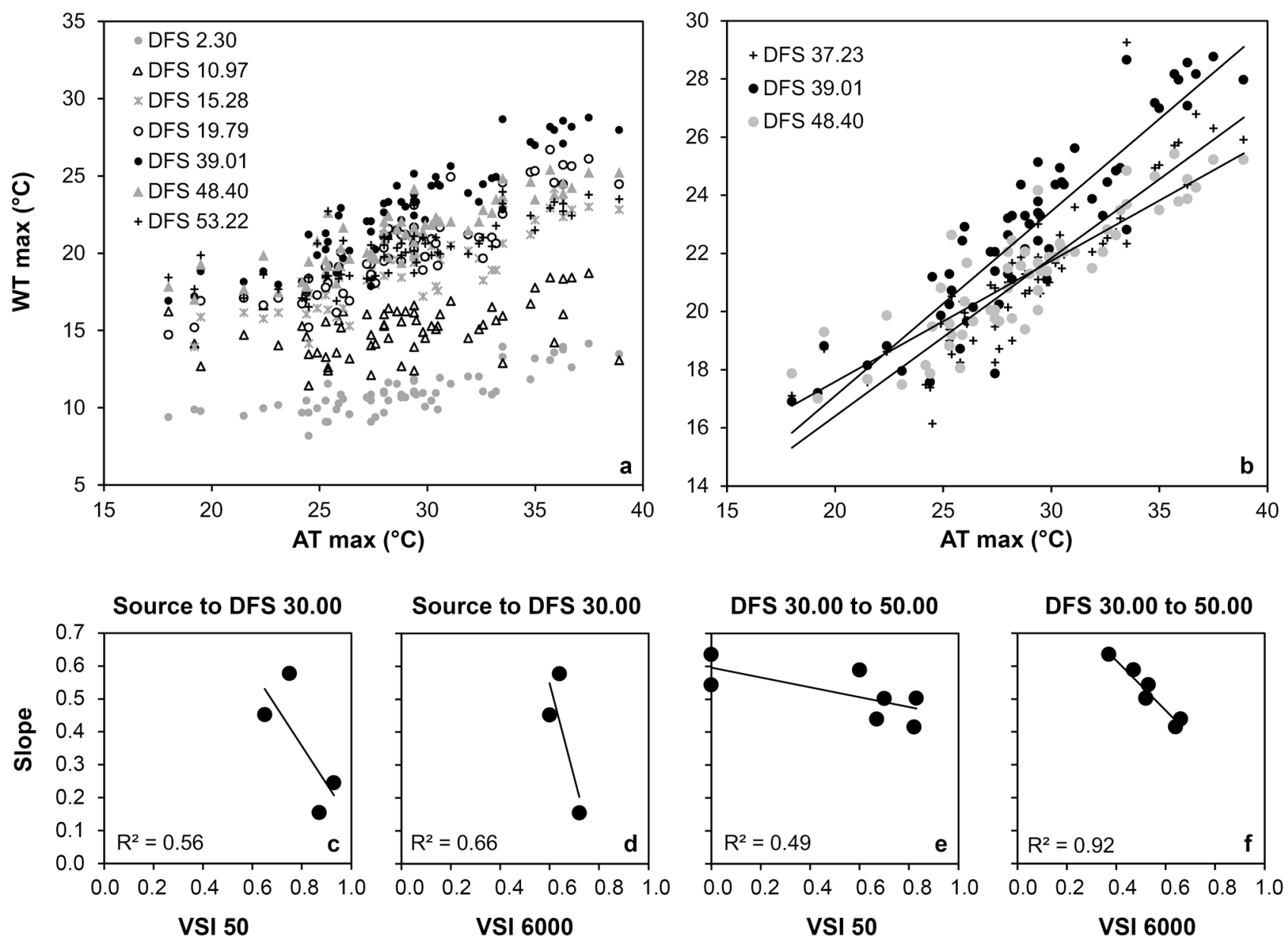

Fig. 8. Maximum water temperatures $\left(\mathrm{WT}_{\max }\right)$ shown as a function of air temperature $(\mathrm{AT})$ at selected WT stations along the whole river stretch (a), and for selected WT stations between distance from source (DSF) 30.00 and DFS 50.00 (b) for summer 2013. (c-f) Show the regressions of vegetation-shading indexes (VSI) to the slopes of the AT to WT regression lines. 
Table 3. Water temperature (WT) change according to an air temperature (AT) change of $2{ }^{\circ} \mathrm{C}$. Abbreviations: DFS $=$ distance from source, $\mathrm{VSI}=$ vegetation shading index.

\begin{tabular}{llllllllll}
\hline DFS $(\mathrm{km})$ & VSI $_{6000}$ & Slope & $R^{2}$ AT/WT & AT change $\left({ }^{\circ} \mathrm{C}\right)$ & AT from $\left({ }^{\circ} \mathrm{C}\right)$ & AT to $\left({ }^{\circ} \mathrm{C}\right)$ & WT from $\left({ }^{\circ} \mathrm{C}\right)$ & WT to $\left({ }^{\circ} \mathrm{C}\right)$ & WT change $\left({ }^{\circ} \mathrm{C}\right)$ \\
\hline 2.3 & & 0.245 & 0.66 & 2 & 30 & 32 & 11.3 & 11.8 & 0.5 \\
10.97 & 0.72 & 0.155 & 0.19 & 2 & 30 & 32 & 15.3 & 15.6 & 0.3 \\
15.28 & 0.6 & 0.452 & 0.72 & 2 & 30 & 32 & 19.5 & 20.4 & 0.9 \\
19.79 & 0.64 & 0.577 & 0.8 & 2 & 30 & 32 & 20.9 & 22.1 & 1.2 \\
30.69 & 0.52 & 0.503 & 0.81 & 2 & 30 & 32 & 21.7 & 22.7 & 1 \\
34.86 & 0.66 & 0.439 & 0.84 & 2 & 30 & 32 & 21.3 & 22.2 & 0.9 \\
37.23 & 0.53 & 0.543 & 0.8 & 2 & 30 & 32 & 21.8 & 22.9 & 1.1 \\
39.01 & 0.37 & 0.635 & 0.83 & 2 & 30 & 32 & 23.5 & 24.7 & 1.3 \\
44.26 & 0.47 & 0.589 & 0.88 & 2 & 30 & 32 & 22.6 & 23.8 & 1.2 \\
45.55 & 0.52 & 0.502 & 0.87 & 2 & 30 & 32 & 22.7 & 23.7 & 1 \\
48.4 & 0.64 & 0.416 & 0.78 & 2 & 30 & 32 & 21.7 & 22.6 & 0.8 \\
53.22 & 0.69 & 0.325 & 0.61 & 2 & 30 & 32 & 20.5 & 21.2 & 0.6 \\
58.79 & 0.69 & 0.512 & 0.82 & 2 & 30 & 32 & 22.6 & 23.6 & 1 \\
61.51 & 0.68 & 0.511 & 0.84 & 2 & 32 & 22.7 & 23.8 & 1 \\
\hline
\end{tabular}

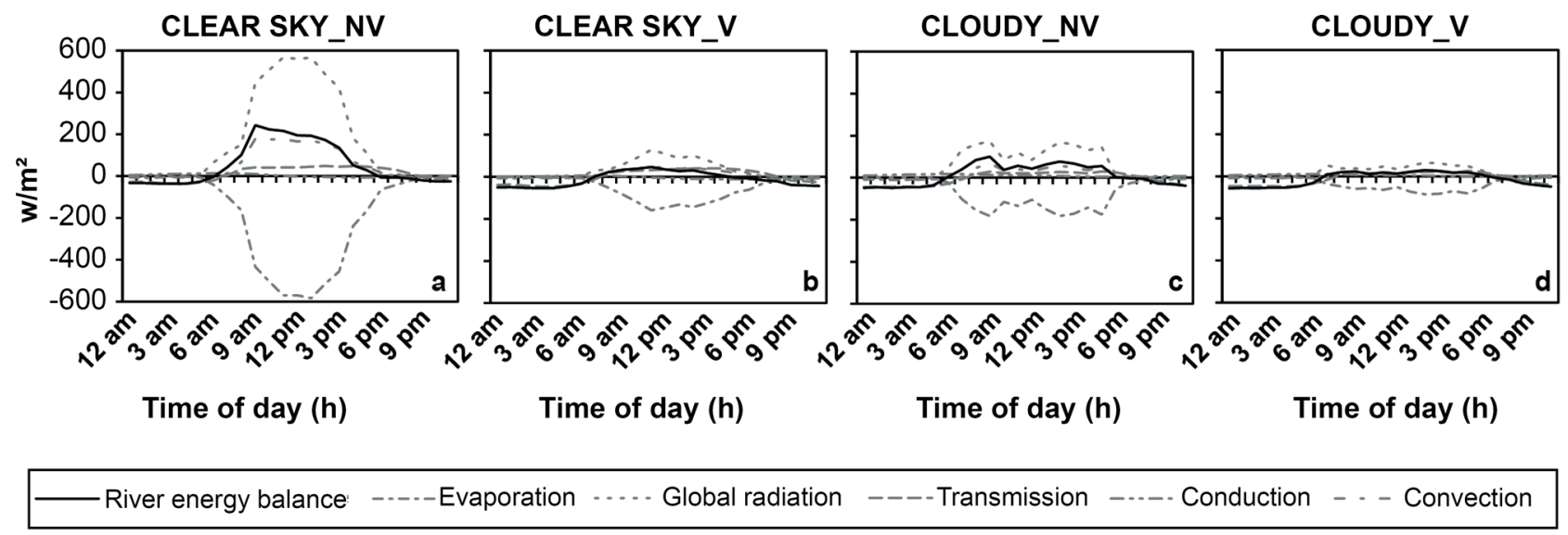

Fig. 9. Daily variations of energy balances for a cloudy (31.7.2016) and a clear sky day (2.8.2016), without vegetation (NV) and with vegetation $(\mathrm{V})$.

individual vegetation parameters. Additionally, it was highly correlated to the GSF with a coefficient of $0.9(p<0.01)$. Depending on river size, different lengths are of relevance, in order to heat the water to a specific temperature. In the present study, the influence of the mean VSIs of different lengths on WT was tested for a stream with $1-1.2 \mathrm{~m}^{3} / \mathrm{s}$ discharge and points to 4-7 km (peak correlation coefficient for $\mathrm{WT}_{\max }$ of -0.82 at $6 \mathrm{~km}$ VSI length) as being an appropriate length. The results are not directly comparable to those of most existing studies which deal with smaller streams with a discharge of up to $0.03 \mathrm{~m}^{3} / \mathrm{s}$ (Story et al., 2003; Johnson, 2004; Rutherford et al., 2004; Moore et al., 2005; Gomi et al., 2006). Rutherford et al. (1997) mentioned $1 \mathrm{st}$ order streams need $250 \mathrm{~m}$ to $500 \mathrm{~m}$; 2 nd order $500 \mathrm{~m}$ to $1.5 \mathrm{~km}$ and $3 \mathrm{rd}$ order $1.5 \mathrm{~km}$ to $5 \mathrm{~km}$ unshaded sections in order to heat the water by $5^{\circ} \mathrm{C}$. Johnson and Wilby (2015) stated that around $0.5 \mathrm{~km}$ of complete shade is necessary to decrease WT by $1{ }^{\circ} \mathrm{C}$ in July at a headwater site; whereas $1.1 \mathrm{~km}$ shade is needed $25 \mathrm{~km}$ downstream. Accordingly, larger rivers need a longer distance to reach the same WT changes than smaller ones.

In the present study, $\mathrm{WT}_{\text {min }}$ and $\mathrm{WT}_{\text {mean }}$ showed a steadily increasing curve from source to DFS 62.55, unaffected by riparian vegetation conditions. However, $\mathrm{WT}_{\max }$ and $\mathrm{WT}_{\text {range }}$ had peaks at unshaded reaches, of up to approximately $4^{\circ} \mathrm{C}$ difference to shaded ones, which followed a steadily increasing curve. These findings correlates well with the findings of Bowler et al. (2012), Johnson (2004) and Webb et al. (2008) which show that if a riverine reach is fully clear cut, the daily $\mathrm{WT}_{\max }$ and $\mathrm{WT}_{\text {range }}$ are particularly affected.

\subsection{Heatwave periods, VSI and their impact on water temperature}

We focused on the comparison between non-heatwave periods (NK) and extreme heatwave days $(\mathrm{K}+)$, as well as clear sky and cloudy days. Only considering AT to divide the 
summer into non-heatwave (NK) and heatwave (K) days, differences in $\mathrm{WT}_{\max }$ of $4.3^{\circ} \mathrm{C}$ were found at all WT stations. Additionally, taking into account cloudiness and discharge conditions, extreme heatwave days $(\mathrm{K}+)$ were selected. Differences in $\mathrm{WT}_{\max }$ to the non-heatwave periods (NK) increased by another $1.2^{\circ} \mathrm{C}$. Many other studies have analysed WT behaviour after clear cut, especially on clear sky and hot days (i.e., Story et al., 2003; Moore et al., 2005; Quinn and Wright-Stow, 2008). Increases of daily $\mathrm{WT}_{\max }$, on nonvegetated sites, of up to $13{ }^{\circ} \mathrm{C}$ were found (Moore et al., 2005).

Additionally, we also analysed the differences between consecutive clear sky and cloudy days to have the same hydrological boundary conditions. The only changing parameter was the radiation input through different cloudiness conditions. On a clear day, the maximum values of the energy balance differed by $159 \mathrm{~W} / \mathrm{m}^{2}$ between areas without vegetation and fully vegetated areas, whereas on cloudy days differences decreased to $39 \mathrm{~W} / \mathrm{m}^{2}$. Garner et al. (2014) also recorded the dramatically reduced energy gains of the river at vegetated sites compared to open sites.

These differing energy inputs to the river were reflected in the different $\mathrm{WT}_{\max }$ during the clear sky days. Open sites with hardly any vegetation showed a $\mathrm{WT}_{\max }$ of up to $27.8^{\circ} \mathrm{C}$, while densely shaded ones showed, on the same day, a $\mathrm{WT}_{\max }$ of $24.9^{\circ} \mathrm{C}$. The lowest $\mathrm{WT}_{\max }$ with $22.7^{\circ} \mathrm{C}$ occurred on a heavily shaded river stretch (mean $\mathrm{VSI}_{50}=0.61$ ). The shading effects of the vegetation have caused a reduction of incoming solar radiation, resulting in a reduction of the increase of WT. Ground water and other potential inflows are acting as cooling factors. Story et al. (2003) concluded from their study that ground water inflow in a shaded reach caused $40 \%$ of the $3{ }^{\circ} \mathrm{C}$ cooling effect in daily $\mathrm{WT}_{\max }$, whereas bed heat conduction and hyporheic exchange caused $60 \%$ of this effect. In our study, ground water influence for a $19.78 \mathrm{~km}$ long river stretch was numerically modelled with a $\mathrm{WT}_{\max }$ decrease of $3.6^{\circ} \mathrm{C}$, neglecting energy exchange with the atmosphere or soil.

\subsection{Water temperature variations}

When considering daily WT variations, the most relevant parameters were daily $\mathrm{WT}_{\max }$ and $\mathrm{WT}_{\text {range. }}$ The results of the present study showed differences between shaded and unshaded sites of up to $4.2^{\circ} \mathrm{C}$ for daily $\mathrm{WT}_{\max }$. The correlation between VSIs and WT changes is high. It is specifically most apparent up to $\mathrm{VSI}_{6000}$ of 0.4 , when the vegetation cover is generally very low. The unshaded areas showed up to $2.6^{\circ} \mathrm{C}$ higher daily $\mathrm{WT}_{\max }$ in the extreme heatwave days $(\mathrm{K}+)$ than fully or patchy shaded ones $\left(\mathrm{VSI}_{6000}\right.$ above 0.4$)$ in the processed area did. This is consistent with Bowler et al. (2012) who concluded that mean $\mathrm{WT}_{\max }$ are up to $4.9^{\circ} \mathrm{C}$ lower at forested riversides than at pasture riversides.

Disregarding all these different conditions and parameters, DFS 39.01, the WT measuring point with the lowest vegetation density $\left(\mathrm{VSI}_{50}=0 ; \mathrm{VSI}_{6000}=0.37\right)$ showed the highest $\mathrm{WT}_{\max }$ in all periods. This highlights the importance and possibilities of riparian vegetation management and the need for at least a degree of riparian vegetation as previously stated in Holzapfel et al. (2013). Rutherford et al. (1997) also emphasizes that a natural shading of $95-99 \%$ radiation reduction is not necessary and $70 \%$ is sufficient. In the present study, sites with $\mathrm{VSI}_{6000}$ of about 0.4 (40\% density) had a significant effect on preventing
WT increase in pre-alpine conditions. Similarly, Correll (2005) stated that from an ecological point of view continuous buffers are more important than wider but fragmented ones.

\subsection{Water temperature influenced by air temperature dependent on VSI}

We found a relationship between $\mathrm{WT}_{\max }$ and $\mathrm{AT}_{\max }$ with an $R^{2}$ of $0.8-0.9$ in summer. Based on this correlation an increase of $2{ }^{\circ} \mathrm{C} \mathrm{AT}_{\max }$, results in an increase of $\mathrm{WT}_{\max }$ of $1.3^{\circ} \mathrm{C}$ for an unshaded reach and $0.8^{\circ} \mathrm{C}$ for a shaded reach. Following a WT increase at an AT change is always dependent on the riparian vegetation situation. Webb and Nobilis (1997) recorded a $\mathrm{R}^{2}$ of 0.97 between $\mathrm{AT}$ and WT for monthly mean values over the entire year. In the summer, between June and August, $\mathrm{R}^{2}$ was only between 0.47 and 0.7 .

\section{Conclusion}

WT is a very important and limiting parameter for the development of riverine life, which is driven by meteorological variables, but also influenced by riparian vegetation stands and many other abiotic factors. This paper focuses explicitly on the impact of different riparian vegetation stands on WT. Most sensitive to changes caused by riparian vegetation is the daily $\mathrm{WT}_{\max }$ followed by the daily $\mathrm{WT}_{\text {range. }}$

In particular, during extreme meteorological events such as heatwave periods, when the river system suffers from highest WTs, vegetation has an impact on WT. In this case, our study has shown that sparse riparian vegetation is sufficient, in order to avoid a WT increase in pre-alpine conditions. VSIs of above 0.4 already achieved good results. On cloudy days the existence of riparian vegetation has no further effects due to solar radiation decrease.

The VSI is a representative parameter which characterises the shading effects of riparian vegetation by its height, width and density. The most relevant considered VSI section length is dependent on specific local boundary conditions. Since the highest correlation between WT and VSI was registered for vegetation stretches of $6000 \mathrm{~m}$, we conclude that for a medium-sized pre-alpine river, restoration practices should consider that discontinuity of riparian vegetation should be less than $6000 \mathrm{~m}$, with more than $40 \%$ dense vegetation in order to minimise WT increases due to unshaded conditions.

The cooling of WT directly by riparian vegetation was not possible, as the energy balance on a clear sky day never dropped below 0 . The findings have shown that riparian vegetation can prevent the WT from an additional increase, and therefore effects such as ground water inflow can have higher impacts. WT directly reacted to changes in AT, riparian vegetation significantly influenced this relationship.

The present study confirmed findings of other studies regarding the influence of riparian vegetation on WT. Each river, however, is a unique system and highly dependent on size, predominant meteorological situations and geographical position. Climate change effects, in particular, put an additional pressure on river ecosystems and its inhabitants, such as fish and benthic invertebrates. To ensure the preservation of habitats for aquatic organisms, riparian vegetation management should be a not dispensable sector in future river planning and management, 
particularly at low water conditions to buffer extreme WT peaks in heatwave periods.

Acknowledgements. This paper was part of the projects BIO_CLIC and LOWFLOW+. The funding for these projects was provided by the Austrian Climate and Energy Fonds (Programm ACRP). Thanks to Viktoria Jachs, Valeria Ledochowski, Wolfgang Bartel and Christoph Hlousek for their assistance in the fieldwork throughout these projects. Statistical analysis was supported by Erwin Lautsch. Hydrological data, meteorological data and aerial photographs were provided by the Legal Water Authorities of Styria and Burgenland and the West Transdanubian Water Direction.

\section{References}

Bowler D, Mant R, Orr H, Hannah D, Pullin A. 2012. What are the effects of wooded riparian zones on stream temperature? Environ Evid 1: 3.

Boyd M, Kasper B. 2003. Analytical Methods for Dynamic Open Channel Heat and Mass Transfer: Methodology for the Heat Source Model Version 7.0.

Broadmeadow S, Nisbet TR. 2004. The effects of riparian forest management on the freshwater environment: a literature review of best management practice. Hydrol Earth Syst Sci 8: 286-305.

Broadmeadow SB, Jones JG, Langford TEL, Shaw PJ, Nisbet TR. 2011. The influence of riparian shade on lowland stream water temperatures in southern England and their viability for brown trout. River Res Appl 27: 226-237.

Caissie D. 2006. The thermal regime of rivers: a review. Freshw Biol 51: 1389-1406.

Cejka A, Dvorak M, Fortman I, et al. 2005. Das Lafnitztal Flusslandschaft im Herzen Europas. Wien: Neuer Wissenschaftlicher Verlag, p. 233.

Correll DL. 2005. Principles of planning and establishment of buffer zones. Ecol Eng 24: 433-439.

Davies-Colley RJ, Meleason MA, Hall RMJ, Rutherford JC. 2009. Modelling the time course of shade, temperature, and wood recovery in streams with riparian forest restoration. $N Z J$ Mar Freshw Res 43: 673-688.

DeWalle DR. 2008. Guidelines for riparian vegetative shade restoration based upon a theoretical shaded-stream model. $J \mathrm{Am}$ Water Resour Assoc 44: 1373-1387.

DeWalle DR. 2010. Modeling stream shade: riparian buffer height and density as important as buffer width. J Am Water Resour Assoc 46: $323-333$.

Evans EC, McGregor GR, Petts GE. 1998. River energy budgets with special reference to river bed processes. Hydrolog Process 12: 575-595.

Fink M, Moog O, Wimmer R. 2000. Fließgewässer - Naturräume Österreichs. Wien: Umweltbundesamt.

Garner G, Malcolm IA, Sadler JP, Hannah DM. 2014. What causes cooling water temperature gradients in a forested stream reach? Hydrol Earth Syst Sci 18: 5361-5376.

Ghermandi A, Vandenberghe V, Benedetti L, Bauwens W, Vanrolleghem PA. 2009. Model-based assessment of shading effect by riparian vegetation on river water quality. Ecol Eng 35: 92-104.

Gomi T, Moore RD, Dhakal AS. 2006. Headwater stream temperature response to clear-cut harvesting with different riparian treatments, coastal British Columbia, Canada. Water Resour Res 42: W08437.
Groom JD, Dent L, Madsen LJ, Fleuret J. 2011. Response of western Oregon (USA) stream temperatures to contemporary forest management. Forest Ecol Manag 262: 1618-1629.

He J, Chu A, Ryan MC, Valeo C, Zaitlin B. 2011. Abiotic influences on dissolved oxygen in a riverine environment. Ecol Eng 37: 1804-1814.

Holzapfel G, Weihs P, Rauch HP. 2013. Use of the Shade-a-lator 6.2 model to assess the shading potential of riparian purple willow (Salix purpurea) coppices on small to medium sized rivers. Ecol Eng 61: 697-705.

Johnson MF, Wilby RL. 2015. Seeing the landscape for the trees: metrics to guide riparian shade management in river catchments. Water Resour Res 51: 3754-3769.

Johnson SL. 2004. Factors influencing stream temperatures in small streams: substrate effects and a shading experiment. Can J Fish Aquat Sci 61: 913-923.

Johnson MF, Wilby RL. 2015. Seeing the landscape for the trees: metrics to guide riparian shade management in river catchments. Water Resour Res 51: 3754-3769.

Kasper B, Boyd M. 2002. TTools 7.0 User Manual. Portland: Oregon Department of Environmental Quality.

Kovats RS, Valentini R, Bouwer LM, et al. 2014. Europe. In: Climate Change 2014: Impacts, Adaptation, and Vulnerability. Part B: Regional Aspects. Contribution of Working Group II to the Fifth Assessment Report of the Intergovernmental Panel on Climate Change. Cambridge, United Kingdom and New York, USA: Cambridge University Press, pp. 1267-1326.

Kyselý J, Kalvová J, Květon V. 2000. Heat waves in the South Moravian region during the period 1961-1995. Studia Geophys Geodaet 44: 57-72.

Laaha G, Parajka J, Viglione A, et al. 2016. A three-pillar approach to assessing climate impacts on low flows. Hydrol Earth Syst Sci 20: 3967-3985.

Leach JA, Moore RD. 2010. Above-stream microclimate and stream surface energy exchanges in a wildfire-disturbed riparian zone. Hydrolog Process 24: 2369-2381.

Logez M, Pont D. 2013. Global warming and potential shift in reference conditions: the case of functional fish-based metrics. Hydrobiologia 704: 417-436.

Matulla C, Schmutz S, Melcher A, Gerersdorfer T, Haas P. 2007. Assessing the impact of a downscaled climate change simulation on the fish fauna in an Inner-Alpine River. Int $J$ Biometeorol 52: 127-137.

Melcher A, Kalny G, Dossi F, et al. 2016. Der Einfluss der Ufervegetation auf die Wassertemperatur unter gewässerspezifischer Berücksichtigung von Fischen und benthischen Evertebraten am Beispiel von Lafnitz und Pinka. Österreichische Wasser- und Abfallwirtschaft.

MeteoSchweiz, B.f.M.u.K., Definition Schönwettertage. http:// www.meteoschweiz.admin.ch/home/klima/vergangenheit/klimader-schweiz/berichte-rund-ums-jahr/altweibersommer.html.

Moore RD, Spittlehouse DL, Story A. 2005. Riparian microclimate and stream temperature response to forest harvesting: a review. J Am Water Resour Assoc 41: 813-834.

Pletterbauer F, Melcher A, Ferreira T, Schmutz S. 2014. Impact of climate change on the structure of fish assemblages in European rivers. Hydrobiologia 744: 235-254.

Poole GC, Berman CH. 2001. An ecological perspective on instream temperature: natural heat dynamics and mechanisms of human-caused thermal degradation. Environ Manag 27: 787-802.

Quinn JM, Wright-Stow AE. 2008. Stream size influences stream temperature impacts and recovery rates after clearfell logging. Forest Ecol Manag 256: 2101-2109. 
Rahel FJ, Olden JD. 2008. Assessing the effects of climate change on aquatic invasive species. Evaluación de los Efectos del Cambio Climático sobre Especies Acuáticas Invasoras. Conserv Biol 22: 521-533.

Rich PM, Wood J, Vieglais DA, Burek K, Webb N. 1999. User Manual for HemiView-Version 2.1. Oregon: Delta-T Devices Ltd, p. 79.

Rutherford JC, Blackett S, Blackett C, Saito L, Davies-Colley RJ. 1997. Predicting the effects of shade on water temperature in small streams. N Z J Mar Freshw Res 31: 707-721.

Rutherford JC, Marsh NA, Davies PM, Bunn SE. 2004. Effects of patchy shade on stream water temperature: how quickly do small streams heat and cool? Mar Freshw Res 55: 737-748.

Sridhar V, Sansone AL, LaMarche J, Dubin T, Lettenmaier DP. 2004. Prediction of stream temperature in forested watersheds. $J \mathrm{Am}$ Water Resour Assoc 40: 197-213.

Story A, Moore RD, Macdonald JS. 2003. Stream temperatures in two shaded reaches below cutblocks and logging roads: downstream cooling linked to subsurface hydrology. Can J For Res 33: $1383-1396$.
Traxler A. 1997. Handbuch des Vegetationsökologischen Monitorings - Methoden, Praxis, angewandte Projekte - Teil A: Methoden. Wien: Umweltbundesamt Österreich, p. 391.

Trimmel H, Gangneux C, Kalny G, Weihs P. 2016. Application of the model 'Heat Source' to assess the influence of meteorological components on stream temperature and simulation accuracy under heat wave conditions. Meteorolog Z 25: 389-406.

Webb BW, Nobilis F. 1997. Long-term perspective on the nature of the air-water temperature relationship: a case study. Hydrolog Process 11: 137-147.

Webb BW, Hannah DM, Moore RD, Brown LE, Nobilis F. 2008. Recent advances in stream and river temperature research. Hydrolog Process 22: 902-918.

Wimmer R, Wintersberger H, Parthl N. 2012. Fließgewässertypisierung in Österreich - Hydromorphologische Leitbilder Band 2: Naturraumbeschreibungen, Bioregionen und Typologie. Vienna: Bundesministerium für Land- und Forstwirtschaft, Umwelt und Wasserwirtschaft - Abt. VII / 1.

Zwieniecki MA, Newton M. 1999. Influence of streamside cover and stream features on temperature trends in forested streams of Western Oregon. Soc Am For West J Appl For 108: 106-113.

Cite this article as: Kalny G, Laaha G, Melcher A, Trimmel H, Weihs P, Rauch HP. 2017. The influence of riparian vegetation shading on water temperature during low flow conditions in a medium sized river. Knowl. Manag. Aquat. Ecosyst., 418, 5. 